\title{
Development and Formation of Shipping Networks in the Contemporary Shipping Environment
}

\author{
Yui Yip Lau \\ Division of Business, Hong Kong Community College, The Hong Kong Polytechnic University, Hong Kong, China
}

Copyright @ 2015 Horizon Research Publishing All rights reserved.

\begin{abstract}
A shipping network is a form of collaboration in the shipping industry where players such as carriers, intermodal service providers, container management service providers, and container terminal operators share resources and assets to develop mutually beneficial strategies and seek operational performance gains. Because of the globalization and the intensified competition in the $21^{\text {st }}$ century, we suggest that the firms apply the concept of agility responding to change in proper ways and due time as well as exploiting changes and taking advantage of them as opportunities in the dynamic business environment. On the basis, we illustrate the key elements are desirable for the development and operation of horizontal and vertical shipping networks to leverage their inherent resources and enhance their capabilities respectively. Theoretical and practical implications of our research findings on the shipping networks development are also discussed in this study.
\end{abstract}

Keyword Horizontal Shipping Networks, Vertical Shipping Networks, Agility, Resources, Capabilities

\section{Introduction}

The shipping industry is confronted with the combination of internal and several external environmental forces create the environmental dynamism in the shipping industry in the $21^{\text {st }}$ century. The environmental dynamism is related to the rapid change and instability of environment [25]. The internal environmental forces include increase in the size and number of organizations leads to modify the industrial structure as well as the external environmental forces include government regulations, accelerate technological change, and change in customer requirements continuously. However, the external environmental elements are uncontrollable leads to the actors are difficult to predict and adopt [25]. Under the challengeable environment, the firms adopt the shipping networks strategies can be investigated through the concept of agility to gain a competitive edge over their competitors. The concept of “Agility" consists of two main factors contains (1) respond to anticipated or unexpected changes with the right product at the right time; and (2) take advantage of changes as opportunities to develop new business [30]. According to Nayloret al. [19], agility is defined as "using market knowledge and a virtual corporation to exploit profitable opportunities in a volatile market place”. Based on that, the network players develop integrated shipping networks either collaborates with other firms or gain organic growth with merge and acquisition [19]. They can enlarge their resources and capabilities in terms of responsiveness, competency, flexibility, and quickness in order to gain the competitive advantage in the macro environment [15]. It brings a significant effect on enhancing firm performance like profitability, sales growth, and customer service so as to maintain competitiveness [4].

There have been few studies to review and discuss on the development and operation of shipping networks [16] [17]. This study investigates the various factors that affect the development of shipping networks. We illustrate the concept of agility to fill the research gap by identifying the key ingredients that are critical to facilitate the development and formation of shipping networks. The concept of agility has gained considerable attention and widespread support from the associated institutions and academicians. There have been numerous of studies have established the concept of agility in the supply chain management [19] [12] [15], but there is relatively limited research to devote the concept of agility on the formation and development of shipping networks. Following this concept, the firms can offer the customers with greater value and stay competitive advantage of shipping industry [12]. Therefore, this study aims to: (1) Explore the driving forces prompt the formation and development of shipping networks; (2) Develop a model that links the relationships between driving forces, agility, the horizontal and vertical shipping network strategies, and firm performance; and (3) Advance the knowledge of the users to design and develop the desirable elements for the horizontal and vertical shipping network strategies to enhance firm performance. This study prompts shipping industry to advance knowledge and explore the possibility of improvement through the development of shipping networks. 


\section{Literature Review}

Shipping networks is service network integration where ocean and land operators collaborate in operations like multimodal transport, joint ownership, and utilization of equipments [22]. Under inter-organizational collaboration, the network members share complementary assets and access the network resources. Access to the network resources is a key driver in developing the shipping networks where the network members collaborate beyond the firm boundaries to achieve the competitiveness in terms of minimize their cost and maximize service advantage [22] [16]. The shipping networks involve managing the operations and the relationships with the actors [16]. The shipping firms either collaborate or consider mergers and acquisitions with other firms to rationalize their resources and offer differentiated services with door to door transportation [28]. On the one hand, the network members are interdependent and reinforce one another. Such as, Cosco, "K" Line, Yang Ming, and Hanjin Shipping have formed the strategic CKYH alliance in 2006. They extended their networks with the establishment of joint feeder networks in 2006. Through collaboration, the operators can increase their purchasing power with the potential of joint purchases; hence it can reduce purchasing costs like vehicles and fuel [5]. On the other hand, some shipping firms prefer "go-it-alone" which deploy internal resources for vertical growth through the mergers and acquisition [11]. Vertical growth is the development of a business across and combination various stages of supply chain in either upward or downward [3]. Heaver [11] mentions that the vertical integration has brought three main advantages. (1) Enjoy the demand complementarily among businesses that the customer demand for shipping service can obtain the benefit from the logistics service at the same time; (2) Opportunity for cost savings by sharing resources and expertise and by reducing transaction costs with the avoidance of duplications among business units; and (3) Strengthen the market power because of increasing initial market share and diversifying the business base. To seek the alternative growth opportunities, the shipping lines expand their core liner business into logistics provider services like Maersk Logistics, OOCL Logistics, P\&O N Logistics, NOL Logistics, NYK Logistics, Yes Logistics, and APL Logistics to offer different service with different shippers' requirements. It can bring the long term profitability to the shipping lines [18]. Hence, the shipping firms can attain the cost and service advantage in the final outcome.

\section{Hypotheses Development}

The multidimensional diversity of driving forces are hypothesized to have a direct effect on the firms adopts the concept of agility to exploit the changes and take advantage of them as opportunities in the challengeable business environment. Our research model also posited that the agility is expected to influence directly on the formulation and implementation of horizontal and vertical shipping network strategies. Developing the horizontal and vertical shipping network brings a positive effect on the firm performance. The linkage of relationships among the variables between the driving forces, agility, the horizontal and vertical shipping network strategies, and firm performance are elaborated on below.

\subsection{Driving forces for the Shipping Networks}

\subsubsection{Social Force}

Thanks to the globalization, it enhances the level of people mobility which the population shifts from one place to another place without any barriers. The shift of population leads to integrate different people with different nationalities in one country. It creates the culturally diverse world in terms of racial and ethnic diversity [3]. The changes of social force constitute a dramatic impact on shipping environment [13]. The shipping firms can employ people with different nationalities and qualifications beyond organizational boundaries to take advantage of globalization [6].

\subsubsection{Political Force}

The political environment brings the significant effects on the shipping industry. Examples are the terrorist attack in New York broke out in 2001, the dockworkers' strikes in California happened in 2002, the SARS epidemic in Asia occurred in 2003 [14]. The shipping industry associations, the government, regulatory bodies like customs and the specific organizations like the International Maritime Organization (IMO) implements the transport policies and regulations to enhance global maritime transport safety and security and facilitate exchange information globally [3] [18].

\subsubsection{Economic Force}

Shipping industry inherent a cyclical pattern of demand and hence they are easily faced by a high fluctuations in dynamic business environment like interest rates, exchange rates, and stock market [16] [3]. On the other hand, there is a fierce competition in shipping markets as a result of the customers continues to increase their demand and expectations in an international trade [30]. Hence, it can facilitate international expansion at a faster pace in the new markets penetration with a lower cost [29].

\subsubsection{Natural Force}

The natural events are difficult to predict and unavoidable, which brings a forceful impact on shipping business activity. The global shipping business are spread all over the world, but the risk of natural events like earthquakes, freezes occur varies with different geographical location [3]. The natural events influence the shipping operations significantly in terms of ship scheduling, ship routing, and calling port selection. The firms need to develop extensive shipping networks with different routings in order to maintain the 
service level in terms of availability and frequency. At the same time, the effect of demand for the goods can be illustrated by the weather. The seaborne commodity trades volume is greatly dependent on the weather. This seasonal factor brings the short-term volatility demand in seaborne commodity trades [16].

\subsubsection{Technological Force}

Technologies are widely used and accelerated changed in the shipping industry such as the revolution of containers, the adoption of advanced and efficient cargo handling equipment and the new design of longer, wider, and bigger-sized vessels [15]. Technological development has revolutionized the shipping business. It not only expedites the growth of carrying capacity, but also facilitates to deliver the raw materials or final products with speedy and at a lower cost in a single journey [16] [3]. Similarly, the advancement of technology encourages the actors to promote effective and efficient flow of information to develop connections with other network members in the shipping industry [16] [18].

The "SPENT" analysis has been given the label of five forces generates the profound effect in the shipping environment. Thus, we conjecture that:

Hypothesis 1: There are a number of factors influencing the formation of shipping networks.

\subsection{Agility}

The agility drivers are created by a variety of the antecedent factors, the different sources of disturbances, and the accelerating rate of global market change [24]. The agility drivers trigger the firms restructure themselves in response to meet the challenges of demanding customers to provide specific and responsiveness services [10]. The perceived uncertainties, continuous changes, and pressures from the battlefields in the market place and internal pressures of firm's growth impose the firms to find new ways of running a business to stay a competitive edge in the business environment [30]. We therefore predict that:

Hypothesis 2: The firms adopt the agility as a result of a varied of matters.

\subsection{Shipping Networks Strategies}

Formulate and implement shipping networks strategies involve what to do, when to do it, and how to do it. At the beginning, the firms need to take strategic analysis of identifying opportunities and threats in the global business environment. Then, formulating an effective shipping strategies that needs to understand competitive situations like the firm's available resources and capabilities, the driving forces of social-culture, political, economic, natural, and technological in the macro environment, the inherent in competitors' strengths and weaknesses, the needs and characteristics of current and potential customers so as to foster the implementation of shipping strategies are compatible in an international business environment [16].
Further to investigate the ingredients of agility, the agility primarily focuses on responsiveness than cost-efficiency to fulfill the customers 'total needs' [10]. Agility is a phenomenon of paradox that requires the shipping firms have a local response and form the right strategies for the global change to enhance flexibility and respond quickly in the changing situations [24]. It facilitates to build up the micro-macro linkage in a rapidly reconfigure of the shipping networks [19]. In order to gain the rapid growth and expansion, the firms either collaborate with others or merge and acquisition in the shipping networks.

Some actors prefer to rely on other firms to survive and accelerate market growth [27]. According to Lun [16], the actors consider the shipping networks as "a transformation process of independent actors and resources into a more closely knit configuration of a network". The actors intent to build up the commitment so as to maintain long-term relationship [9]. European Union [8] explains the notion of horizontal cooperation as "concerted practices between companies operating at the same levels in the market." The actors remove any barrier and boundaries to facilitate virtual integration in terms of flow of resources and information in the shipping networks [12]. The network members are strategic interdependence to share capacity and fixed assets like facilities and vehicles with others to attain cost advantage and service integration [11]. Therefore, we speculate that:

Hypothesis 3a: The agility positively affects the development of horizontal shipping network strategy.

Hypothesis 3b: The agility positively affects the development of vertical shipping network strategy.

\subsection{Firm Performance}

The shipping networks performance measurement assesses the relationships between shipping networks activities and business performance [21]. The firm performance may be conceptualized as a measure to the firm's goal can be achieved [7]. The determinant of the success of adoption the shipping networks strategies is whether the adoption is closely related to performance improvement, that is higher profitability, sales growth, and overall customer satisfaction [17]. The shipping networks can stimulate service integration and strengthen service conformity [1]. The perceived benefits of adopting shipping networks strategies have been illustrated in a variety of literature [22] [13] [5]. For instance, Brouthers et al. [2] examined that buying existing firms can increase market power and generates economies of scale. Sarkar et al.[23] suggested that collaborating with other firms can increase the firm's market orientation in terms of sales growth, market share, product development, and market development. Notteboom [20] found that joining forces or merge and acquisition with other firms lead to profit maximization and cost minimization. Generally, the literature supports the adoption of shipping networks strategies can further reduce the gap between what the customers' needs and what the 
actors offer in the shipping networks [26]. Thus, we hypothesized the above as follows:

Hypothesis 4a: The extent of adopting shipping network strategy by horizontal is positively correlated with firm performance.

Hypothesis 4b: The extent of adopting shipping network strategy by vertical is positively correlated with firm performance.

\section{Conclusions}

Our study has two-fold implications. From a theoretical perspective, we apply the concept of agility to open up a new area in the shipping industry. The injection of new idea "agility" suggests the firms respond to the dynamic business environment in proper ways and due time so as to gain competitive advantage and first mover advantage. From a managerial perspective, this study explores the current internal and external situation of shipping industry. This provides a useful reference for the firms to evaluate their inherent resources and capabilities while anticipate their opportunities and threats in the changing business environment. The firms need to explore their business strategies to leverage their inherent resources and capabilities to take advantage of changing business environment as opportunities.

This study is one of a few studies to discuss and analysis on the shipping networks analysis. However, we should take account of some limitations and pitfalls in this study. We conducted a theoretical study that this research is initial attempts to apply the concept of agility in the shipping networks. In the future, we will conduct a large-scale longitudinal study in the other countries to investigate the hypothesis relationships and generalize our research results. Besides, we will access the objective data like the firm size, the annual turnover to verify our findings in future research. A detailed study should focus more on the firms formulate strategies and establish the management theories of resource-based theory to critically assess the firms inherent resources and capabilities on the development and formation of shipping networks.

\section{REFERENCES}

[1] Bergantino, A. and Veenstra, W.A. (2002), Interconnection and Coordination: An Application of Network Theory to Liner Shipping, International Journal of Maritime Economics, Vol. 4, No.3, pp.231-248.

[2] Brouthers, K.D., Hastenburg, P. and Ven, J. (1998), If Most Mergers Fail Why Are They So Popular?, Long Range Planning, Vol. 31, No. 3, pp. 347-353.

[3] Campbell, D., Stonehouse, G. and Houston, B. (2007), Business Strategy, Burlington: Elsevier.
[4] Cheng, T.C.E. and Choy, W.C.P. (2007), Measuring Success Factors of Quality Management in the Shipping Industry, Maritime Economics and Logistics, Vol. 9, No. 3, pp. 234-253.

[5] Cruijssen, F., Cools, M. and Dullaert, W. (2007), Horizontal Cooperation in Logistics: And Opportunities Impediments, Transportation Research Part E, Vol. 43, No. 2, pp. 129-142.

[6] Duncan, R.B. (1972), Characteristics of Organizational Environments and Perceived Environmental Uncertainty, Administrative Science Quarterly, Vol. 17, No. 3, pp. 313-327.

[7] Ellinger, A.E., Daugherty, P.J., Keller, S.B. (2000), The Relationship Between Marketing/Logistics Interdepartmental Integration and Performance In U.S. Manufacturing Firms: An Empirical Study, Journal of Business Logistics, Vol. 21, No. 1, pp.1-22.

[8] European Union (2001), Guidelines on the Applicability of Article 81 of the EC Treaty to Horizontal Cooperation Agreements, European Commission Notice 2001/C, 3/02.

[9] Goerzen, A. (2007), Alliance Networks and Firm Performance: The Impact of Repeated Partnerships, Strategic Management Journal, Vol. 28, No. 5, pp. 487-509.

[10] Gunasekaran, A. (1999), Agile Manufacturing: A Framework for Research and Development, International Journal of Production Economics, Vol. 62, No. 1, pp. 87-105.

[11] Heaver, T.D. (2001), The Evolving Roles of Shipping Lines in International Logistics, International Journal of Maritime Economics, Vol. 4, No. 3, pp. 210-230.

[12] Hoek, R.I., Harrison, A. and Christopher, M. (2001), Measuring Agile Capabilities in the Supply Chain, International Journal of Operations and Production Management, Vol. 21, No. 1, pp. 126-147.

[13] Kerin, R.A., Hartley, S.W., Berkowitz, E.N. and Rudelius, W. (2006), Marketing, New York: McGraw Hill.

[14] Lee, H.L. (2004), The Triple - A Supply Chain, Harvard Business Review, Vol. 83,No. 10 pp. 102-112.

[15] Lin, C.T., Chiu, H. and Chu, P.Y. (2006), Agility Index in the Supply Chain, International Journal of Production Economics, Vol. 100, No. 2, pp. 285-299.

[16] Lun, Y.H.V., Lai, K.H. and Cheng, T.C.E. (2006), Shipping and Transport Logistics, Singapore: McGraw Hill.

[17] Lun, Y.H.V., Lai, K.H. and Cheng, T.C.E. (2009), Electronic Commerce in Container Shipping, Shipping and Transport Logistics Book Series, Vol. 1, pp. 35-50.

[18] Lun, Y.H.V., Wong, C.W.Y., Lai, K.H. and Cheng, T.C.E. (2008), Institutional Perspective on the Adoption of Technology for the Security Enhancement of Container Transport, Transport Reviews, Vol. 28, No. 1, pp. 21-33.

[19] Naylor, J.B., Naim, M.M. and Berry, D. (1999),Legality: Integrating the Lean and Agile Manufacturing Paradigms in the Total Supply Chain, International Journal of Production Economics, Vol. 62, No. 2, pp. 107-118.

[20] Notteboom, T.E. (2002), Consolidation and Contestability in the European Container Handling Industry, Maritime Policy and Management, Vol. 29, No. 3, pp. 257-269. 
[21] O’Sullivan, D. and Abela, A.V. (2007), Marketing Performance Measurement Ability and Firm Performance, Journal of Marketing, Vol. 71, No. 2, pp. 79-93.

[22] Ryoo, D.K. and Thanopoulou, H.A. (1999), Liner Alliances in the Globalization Era: A Strategic Tool for Asian Container Carriers, Maritime Policy and Management, Vol. 26, No. 4, pp. 349-367.

[23] Sarkar, M.B., Echambadi, R.A.J. and Harrison, J.S. (2001), Alliance Entrepreneurship and Firm Market Performance, Strategic Management Journal, Vol. 22, No. 7, pp. 701-711.

[24] Sharp, J.M., Irani, Z. and Desai, S. (1999), Working Towards Agile Manufacturing in the UK Industry, International Journal of Production Economics, Vol. 62, No. 2, pp. 155-169.

[25] Simerly, R.L., Li, M. (2000), Environmental Dynamism, Capital Structure and Performance: A Theoretical Integration and an Empirical Test, Strategic Management Journal, Vol.
21, No. 1, pp. 31-49.

[26] Slater, S.F. and Narver, J.C. (1995), Market Orientation and the Learning Organization, Journal of Marketing, Vol. 59, No. 3, pp. 63-74.

[27] Smart, C. and Vertinsky, I. (1984), Strategy and the Environment: AStudy of Corporate Responses to Crises, Strategic Management Journal, Vol. 5, No. 3, pp. 199-213.

[28] Song, D.W. (2003), Port Co-opetition in Concept and Practice, Maritime Policy and Management, Vol. 30, No. 1, pp. 29-44.

[29] Todeva, E. and Knoke, D. (2005), Strategic Alliances and Models of Collaboration, Management Decision, Vol. 43, No. 1, pp. 123-148.

[30] Zhang, Z. and Sharifi, H. (2000), A Methodology for Achieving Agility in Manufacturing Organizations, International Journal of Operations and Production Management, Vol. 20, No. 4, pp. 496-512. 